\title{
Mechanisms of Schwann cell plasticity involved in peripheral nerve repair after injury
}

\author{
Gianluigi Nocera $^{1} \cdot$ Claire Jacob $^{1}$ (1)
}

Received: 4 January 2020 / Revised: 9 March 2020 / Accepted: 30 March 2020 / Published online: 10 April 2020

(c) The Author(s) 2020

\begin{abstract}
The great plasticity of Schwann cells (SCs), the myelinating glia of the peripheral nervous system (PNS), is a critical feature in the context of peripheral nerve regeneration following traumatic injuries and peripheral neuropathies. After a nerve damage, SCs are rapidly activated by injury-induced signals and respond by entering the repair program. During the repair program, SCs undergo dynamic cell reprogramming and morphogenic changes aimed at promoting nerve regeneration and functional recovery. SCs convert into a repair phenotype, activate negative regulators of myelination and demyelinate the damaged nerve. Moreover, they express many genes typical of their immature state as well as numerous de-novo genes. These genes modulate and drive the regeneration process by promoting neuronal survival, damaged axon disintegration, myelin clearance, axonal regrowth and guidance to their former target, and by finally remyelinating the regenerated axon. Many signaling pathways, transcriptional regulators and epigenetic mechanisms regulate these events. In this review, we discuss the main steps of the repair program with a particular focus on the molecular mechanisms that regulate SC plasticity following peripheral nerve injury.
\end{abstract}

Keywords Schwann cell $\cdot$ Plasticity $\cdot$ Reprogramming $\cdot$ Chromatin remodeling enzymes $\cdot$ Transcription factors $\cdot$ Signaling pathways $\cdot$ Nerve injury and repair $\cdot$ Axonal regeneration $\cdot$ Remyelination

\section{Schwann cells and peripheral nerve injuries}

Axonal repair in the central nervous system (CNS) is extremely limited after injury. In contrast, the PNS exhibits a high regenerative capacity. This ability is to a large extent due to the remarkable plasticity of SCs. During development, myelinating SCs form a one-to-one relationship with large caliber axons and wrap them in a myelin sheath, while non-myelinating SCs, also called Remak SCs, surround multiple small caliber axons without producing myelin. Upon axon injury, myelinating and nonmyelinating SCs undergo extensive reprogramming that promotes and guides axonal repair. SCs lose contact with and demyelinate the distal stump axon and convert into a repair phenotype. This phenotypic transformation involves the downregulation of several pro-myelinating genes.

Claire Jacob

cjacob@uni-mainz.de

1 Faculty of Biology, Institute of Developmental Biology and Neurobiology, Johannes Gutenberg University, Mainz, Germany
Repair SCs are characterized by a specific profile which enables the regeneration process. SC reprogramming involves the upregulation of several genes and the activation of multiple transcriptional mechanisms [1-3]. Among the main players, c-Jun, mitogen-activated protein kinase (MAPK) pathways, Sonic Hedgehog (Shh) and chromatin modifications control and regulate the repair program. In the injured site, repair SCs participate in the disintegration and removal of damaged axons during the process of Wallerian degeneration and assist myelin debris clearance to create a regrowth favorable environment. Myelin debris clearance is achieved by the digestion of both intrinsic and extrinsic myelin fragments by means of myelinophagy and phagocytosis and the recruitment and activation of invading macrophages $[4,5]$. Afterwards, SCs secrete trophic factors to support survival of damaged neurons and promote axon regrowth $[1,6]$. Repair and Remak SCs also extend long parallel processes and align in tracts called bands of Büngner to guide the regrowing axon back to innervate its former target $[3,7]$. Finally, SCs proliferate, upregulate pro-myelinating genes, re-differentiate into 
Fig. 1 Repair program in the PNS. Illustration of the main steps of the repair program orchestrated by SCs after peripheral nerve injury. Each step shows a schematic representation of a single neuron (blue) interacting with SCs (light yellow) within an adult peripheral nerve undergoing a traumatic lesion. In step 4 , macrophages (green cells) help SCs to clear axon and myelin debris

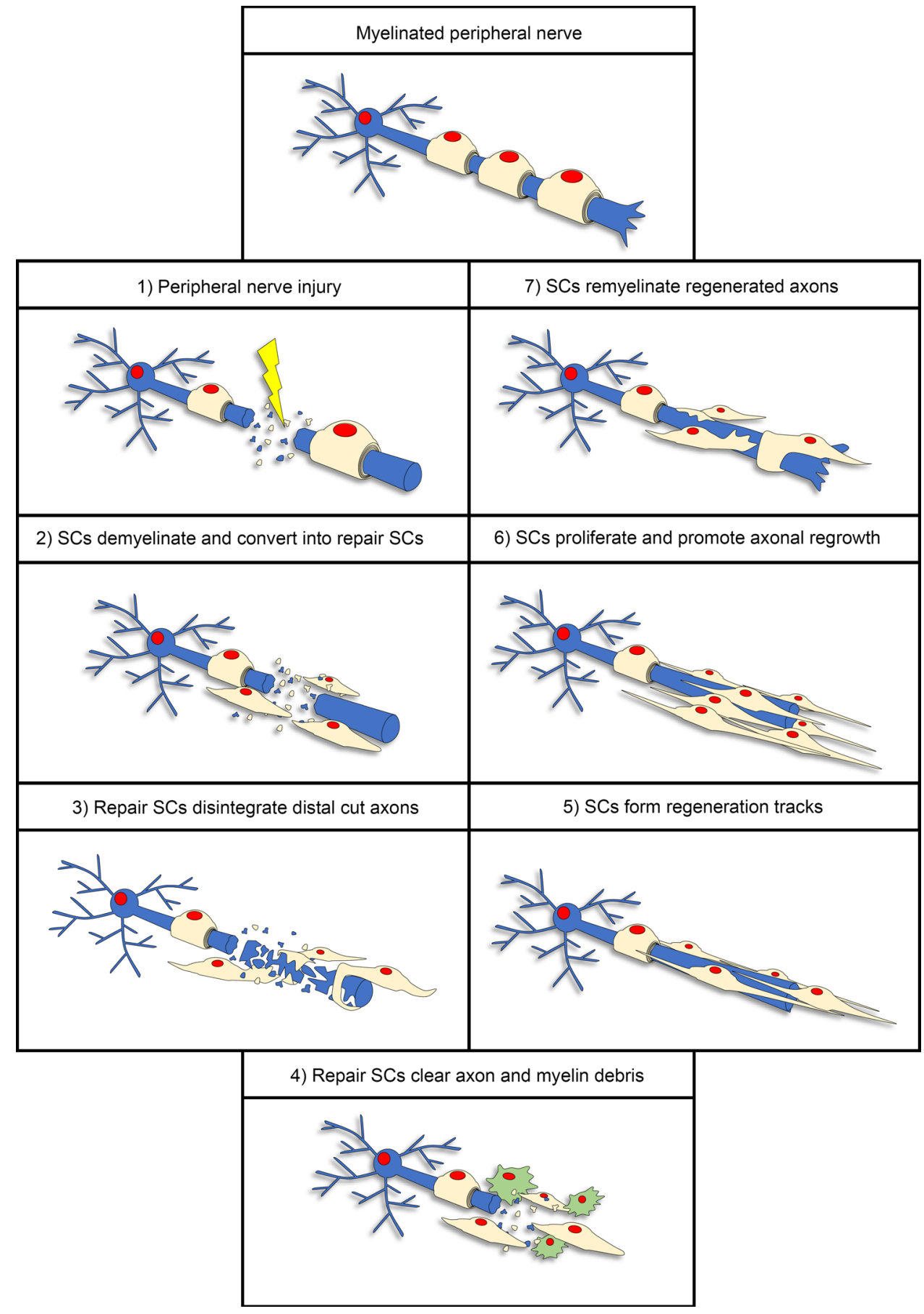

myelinating SCs and remyelinate the regenerated axon. An overview of the repair program is illustrated in Fig. 1. This repair machinery requires a dynamic and orchestrated regulation of SC plasticity and reprogramming following axon injury. Although the underlying molecular mechanisms remain still partially understood, several research groups have significantly contributed to our current understanding of how the key steps involved in the PNS repair program are controlled, which we will discuss in the next chapters of this review.

\section{Nerve injury and methods in regeneration research}

The severity of peripheral nerve injuries is classified depending on whether demyelination occurs and on the extent of axonal and connective tissue damage [8]. The mildest form 
called neurapraxia is characterized by local demyelination without axon or connective tissue lesion. Axonal lesion in addition to demyelination but with preserved connective tissue is a more severe injury called axonotmesis, while in the most severe form of injury, which is called neurotmesis, axons and the connective tissue are fully transected [9]. A more detailed classification with five different severity degrees followed Seddon's classification [10]. SC plasticity and regeneration potential have been extensively studied both in vivo and in vitro. In vivo studies involved the use of wild type and transgenic animals. Among the methods used to study regeneration, nerve transection and crush injury models are the most commonly employed. The crush injury model offers some particular advantages. It is typically performed through an acute traumatic compression of the nerve and it interrupts all the axons but preserves the SC basal lamina. This allows for an optimal regeneration and to investigate the SC regeneration potential. Rats and mice are often used in research for sciatic nerve lesions to model human PNS lesions [11, 12]. In vitro studies mainly involve the use of cell lines, primary or organotypic ex vivo cell cultures. These models present great ethical advantages and they allow to investigate signalling pathways specifically induced by different molecules and drugs on SCs and/or neurons $[13,14]$. Although they are unable to fully predict what happens at the whole organ level, primary SC/neuron cocultures have been useful PNS models to investigate the molecular mechanisms involved in axonal regrowth fostered by SCs and remyelination. Moreover, microfluidic devices, which allow the compartmentalization of neuronal cell bodies, axons and myelinating cells, have demonstrated to be useful in in vitro research $[15,16]$.

\section{Schwann cell reprogramming}

SC reprogramming following peripheral nerve injury can be divided in two main partially overlapping processes: SC demyelination and conversion or transdifferentiation into repair SCs $[5,17]$. The demyelination process is characterized by the repression of pro-myelinating genes such as Early growth response 2 (Erg2 or Krox20) and of myelin genes including Myelin basic protein (Mbp), Myelin protein zero (Mpz or P0), Peripheral myelin protein 22 (Pmp22) and Myelin associated glycoprotein (Mag). Moreover, genes typically expressed during development including genes coding for L1, neural cell adhesion molecule (NCAM), p75 neurotrophin receptor (p75NTR) and glial fibrillary acidic protein (GFAP), are re-expressed or upregulated [17, 18]. However, repair SCs differ from immature SCs during development by several aspects. Indeed, they are characterized by de-novo expression of genes that include Olig 1 and Shh and by the upregulation of many proteins involved in the regeneration process. Among those, (1) c-Jun, the main driver of the SC-dependent repair program, glial cell-derived neurotrophic factor (GDNF), brain-derived neurotrophic factor (BDNF), neurotrophin-3 (NT3), artemin, nerve growth factor (NGF), vascular endothelial growth factor (VEGF), and VEGF receptor 1 support the survival of injured neurons and promote the regrowth of proximal axons $[1,16$, 18-20]; (2) leukemia inhibitory factor (LIF), interleukin-1 $\alpha$ (IL-1 $\alpha$ ) and $-1 \beta$ (IL-1 $\beta$ ), tumor necrosis factor- $\alpha$ (TNF$\alpha)$ and monocyte chemotactic protein 1 (MCP-1) initiate the immune response, promote macrophage invasion and activation, blood vessel formation and myelin breakdown [1, 21-24]; (3) c-Jun, SRY-box 2 (Sox2) and neuregulin 1 (NRG1) are involved in SC morphological changes and axoglial interactions, in the formation of a nerve bridge in case of nerve transection and of the regeneration tracks along which axons regrow; (4) zinc finger E-box-binding homeobox 2 (Zeb2), nuclear factor-kappa B (NF-kB) and histone deacetylases 1 and 2 (HDAC1/2) are involved in the remyelination of the regenerated axon [25-29]. A summary of the main factors involved in the regeneration process is illustrated in Fig. 2, while a more detailed description of the main factors and signaling pathways with the most recent findings is discussed below.

\section{Epigenetic regulation and other chromatin-remodeling enzyme functions}

The complexity of the repair program requires a strict orchestration of gene expression and signalling pathways. Among the many levels of regulation, epigenetic regulation and chromatin-remodeling enzymes have been related to many aspects of SC development, maintenance and plasticity after peripheral nerve injury [2]. In SCs of uninjured nerves, Polycomb repressive complex 2 (PCR2) adds trimethyl marks to histone $\mathrm{H} 3$ lysine 27 (H3K27me3) on promoter regions of several genes to repress the expression of these genes and PRC2 inactivation results in the induction of genes that are normally upregulated following peripheral nerve injury [30]. Upon injury, H3K27 demethylation together with $\mathrm{H} 3 \mathrm{~K} 4$ methylation at promoter regions and $\mathrm{H} 3 \mathrm{~K} 27$ acetylation at enhancer regions promote the activation of injury-induced genes expressed during the repair program such as Shh and Gdnf [2, 30-32]. Recently, much research has focused on the functions of HDACs. By deacetylating and controlling the activity of non-histone targets including transcription factors, these enzymes have been shown to play key roles in the regulation of SC behavior following peripheral nerve lesion. HDAC1 and HDAC2, which belong to class 1 HDACs, have crucial functions in SC development including myelination and in PNS maintenance during adulthood $[1,24,33]$. Moreover, they are 


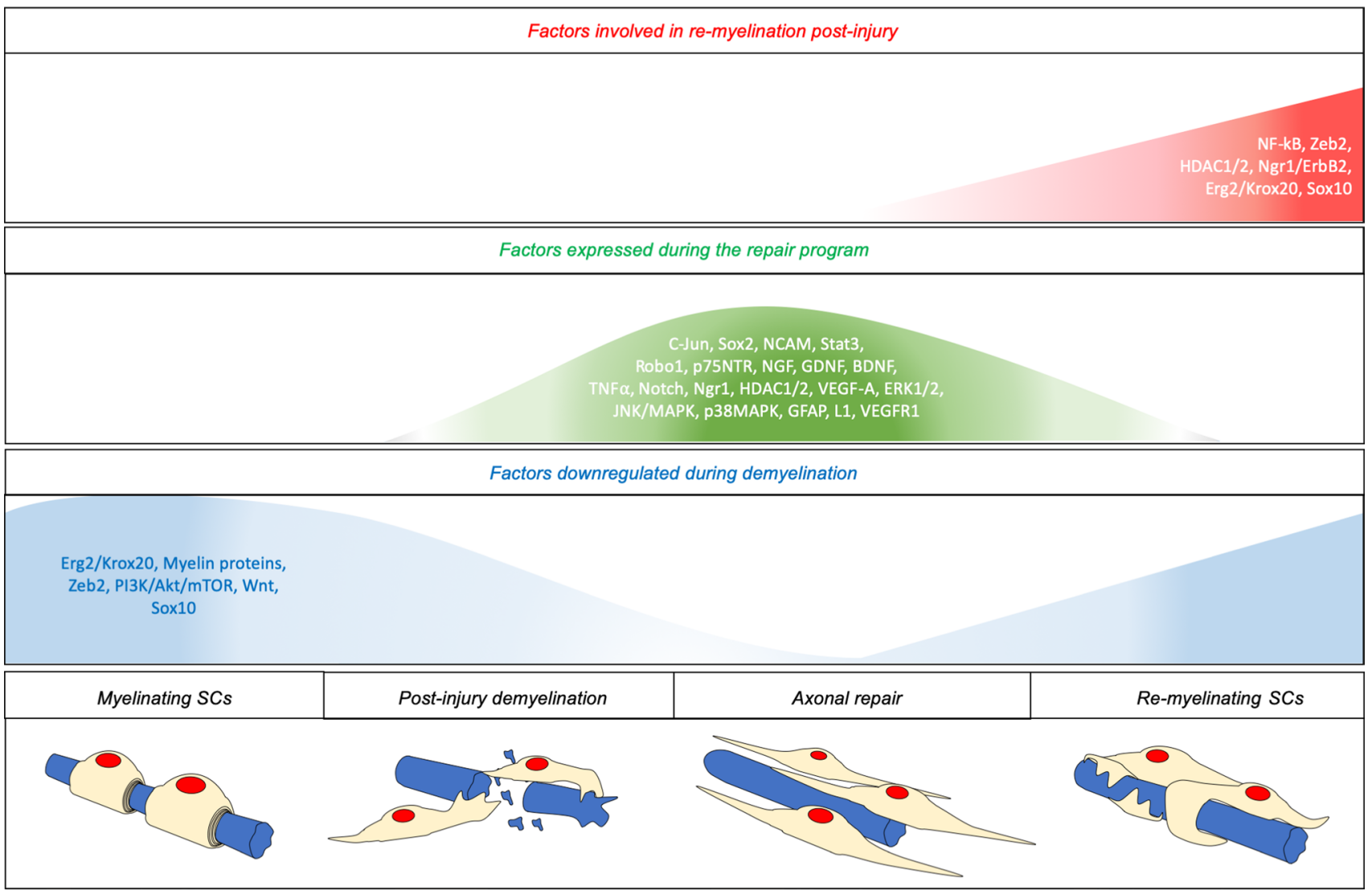

Fig. 2 Summary of the main factors regulated after peripheral nerve injury. Overview of factors downregulated during demyelination (blue area), factors expressed during the repair program (green area), and factors involved in re-myelination post-injury (red area). Uphill areas indicate a high expression, whereas downhill areas indicate a low expression. Regulation of factors is illustrated throughout the different steps of the regeneration process

Indeed, HDAC3 inactivation by pharmacological inhibition or by conditional deletion in SCs enhances myelin growth after peripheral nerve injury or during PNS maintenance in adulthood [35, 36], which could thus be potentially interesting in human medicine to improve PNS remyelination after injury and prevent demyelination during aging or in the context of peripheral neuropathies. He et al. [35] and Rosenberg et al. [36] propose, however, two very different mechanisms of action for HDAC3: while $\mathrm{He}$ et al. [35] claim that HDAC3 antagonizes the neuregulin-PI3K-AKT signaling pathway and coordinates with p300 histone acetyltransferase to repress the promyelinating program by epigenetic silencing and to activate genes that inhibit SC myelination, Rosenberg et al. [36] found that HDAC3 allows to switch off the HDAC1/2-dependent biogenic myelination program to enter the homeostatic myelination program in adult peripheral nerves. Clarification of this process is, therefore, needed. Epigenetic regulation has been also shown to have critical functions in ensuring a correct functioning of SCs during the repair program. Indeed, during demyelination, SCs reenter the cell cycle and proliferate. To prevent uncontrolled 
proliferation that could lead to tumor formation, SCs upregulate JMJD3 after a nerve lesion, which demethylates H3K27 at promoter regions and de-represses the tumor-suppressor p19Arf and p16Ink4a [37].

\section{Axon and myelin clearance}

To be efficient, the regenerative process requires the generation of a favorable environment that fosters axonal repair. Rapidly after injury, SCs promote the disintegration of distal cut axons [16] and their clearance, together with invading macrophages [38-40]. The presence of persistent axon fragments inhibits the regeneration of axon branches [21] and leads to delayed axonal regrowth [16, $41,42]$. We recently showed that after a peripheral nerve lesion, SCs form constricting actomyosin spheres along unfragmented distal cut axons to accelerate their disintegration [16]. Interestingly, this mechanism is triggered by distal cut axons that upregulate the VEGFR1 agonist PIGF by injury-induced local translation, resulting in the activation of a VEGFR1/Pak1/F-actin axis in SCs [16]. Moreover, after injury myelin in the distal injured axon site breaks down into small intracellular and extracellular fragments and debris. Myelin debris act as an inhibitor of axon regeneration by creating a non-permissive environment which impairs axonal regrowth. However, PNS myelin is less inhibitory than CNS myelin [43] and numerous mechanisms in the PNS contribute to myelin digestion after nerve injury. In the first phase after nerve damage, intrinsic myelin is digested by SCs through a type of selective macro-autophagy called myelinophagy [4]. During this process, intracellular myelin debris are sequestered by a double membrane phagophore, which matures into an autophagosome and finally fuses with a lysosome triggering the degradation of the autophagic cargo. Myelinophagy appears to be essential during the early stages after injury, as genetic and/or pharmacological inhibition of autophagy inhibits myelin protein and lipid breakdown in injured nerves [4]. During the second phase post injury, SCs and invading macrophages collaborate to clear extrinsic myelin. SCs engulf and digest myelin debris by receptor-mediated phagocytosis. In particular, Axl and Mertk, two well-characterized receptors belonging to the TAM family of phagocytic receptors, appear to be critical for myelin digestion, as shown by impaired myelin degradation in SCs lacking these receptors [44]. SCs participate to macrophage recruitment to the injured site. Macrophages play a critical role in peripheral nerve injury. Besides contributing to myelin clearance, they participate in the inflammatory response, foster axon debris removal and regulate the injured site microenvironment, which allows for efficient regeneration. During the peak phase of myelin clearance after injury, repair SCs express high levels of several growth factors and chemoattractant cytokines including MCP-1, GDNF, interleukin-6 (IL-6) and LIF. These factors act by promoting the recruitment and the induction of both pro- and anti-inflammatory macrophages (M1- and M2-macrophages) [45-48].

\section{Signaling pathways and transcription factors}

\section{NRG1 and its dual role in regeneration}

It has been already established that the NRG1/ErbB signaling pathway is critically involved in axoglial communication regulating myelination and the thickness of the myelin sheath during PNS development, and in SC proliferation, survival and migration [49-57]. During adulthood, different NRG1 isoforms play different roles. Transmembrane NRG1 isoforms are expressed by myelinated axons, while soluble NRG1 isoforms are expressed by Schwann cells immediately after injury. NRG1/ErbB signaling is highly regulated following nerve injury [58-61]. Indeed, NRG1 and ErbB2/3 receptor levels significantly increase in distal nerve stump SCs [59]. In contrast, the expression of NRG1 by peripheral neurons initially decreases and then increases as axons reinnervate their targets [59, 62]. NRG1 type III expression in neurons appears to be required for timely repair and remyelination. Indeed, transgenic animals in which axons lack NRG1 type III show slower regeneration after nerve crush and display a significant transient impairment in remyelination following injury [27, 63, 64]. NRG1/ErbB signaling is regulated by beta-site amyloid precursor protein cleaving enzyme 1 (BACE1), which cleaves and activates NRG1 type III and is necessary for myelination during development [65, 66]. Moreover, mice lacking BACE1 display delayed remyelination, reduced myelin thickness in remyelinated axons and a general reduction in the total number of remyelinated axons. However, these mutants surprisingly show faster axon and myelin debris clearance and axon regeneration and reinnervation of their target $[67,68]$. In addition to axonal NRG1 type III, NRG1 type I expressed by SCs upon injury is necessary for remyelination after lesion [69]. Based on these evidences, a number of studies focused on the application of exogenous NRG1 to increase NRG1 levels and improve axonal regeneration, remyelination and functional recovery following peripheral nerve injury [27, 69-72]. Interestingly, rats treated with an ErbB2 receptor inhibitor display a reduction of demyelination after transection [73], which suggests that the NRG1/ErbB signaling may also have a function in myelin breakdown. The pathway downstream NRG1/ErbB signaling is still not fully characterized. While some studies propose that the activation of ErbB2/3 in SCs by NRG1 
promotes ERK activation and induces SC demyelination and conversion into repair cells or remyelination $[69,74]$, others suggest that NRG1 triggers Rac/JNK activation [13, 75]. It is important to point out that the apparently opposite functions of the NRG1/ErbB signaling seem to be due to different stimulation levels of the pathway and that an uncontrolled or inappropriate induction of the NRG1/ErbB signaling may be harmful as it could lead to demyelinating neuropathy as well as neoplastic conditions [74, 76-78].

\section{c-Jun}

c-Jun is a key transcription factor involved in SC reprogramming and response to peripheral nerve injury. Its expression is constitutively low, both during development and in adult nerves, and it does not appear to be crucial in adult uninjured nerves, as transgenic animals carrying conditional deletion of c-Jun (c-Jun cKO) in SCs appear normal. By contrast, $c$-Jun gene expression rapidly increases following nerve injury and in some peripheral neuropathies and is critical during axonal regeneration. Indeed, c-Jun cKO mice exhibit a delayed demyelination, decreased neuronal survival and limited regeneration capacity [3, 79-83]. In injured nerves, c-Jun affects the expression of hundreds of genes and regulates several aspects of the regeneration process $[3,19]$. Several lines of evidence support the idea that c-Jun is directly involved in and drives SC demyelination and transdifferentiation into a repair phenotype. As demyelination requires the downregulation of several pro-myelinating genes, c-Jun antagonistic expression with Krox20 led to identify this factor as the main negative regulator of myelination driving demyelination. Indeed, enforced c-Jun expression is enough to inhibit myelination in neuron/SC cocultures [3, 80, 81]. c-Jun functions have been also correlated with myelin breakdown during the process of myelin clearance, as shown by a significant reduction in myelin debris degradation following nerve transection in transgenic mice carrying a conditional deletion of c-Jun in SCs. Although this impairment is correlated with a deficit in the myelinophagic pathway, it is unclear whether this effect is related to myelinophagy only or to a defect in both myelinophagy and myelin phagocytosis. Myelin breakdown impairment could also be related to a defect in macrophage activation, as in these mutants, macrophages contain an increased amount of lipid droplets as compared to controls. In addition, evidence supports the idea that c-Jun also acts as an intrinsic determinant of SC morphology and controls the structure of the regeneration tracks that guide growing axons back to re-innervate their former targets [3, 4, 84]. In conclusion, c-Jun appears to be a global regulator of the SC-dependent repair program. Several signalling pathways have been proposed to be upstream of and to regulate c-Jun expression. Among these, the MAPK pathways extracellular signal-regulated protein kinases (ERK)1/2, c-Jun N terminal kinase (JNK) and p38 are plausible candidates, all of them being activated following nerve injury [85-87].

\section{MAPK functions in nerve repair}

Many MAPKs have been involved in SC plasticity and axonal regeneration. Their role in the repair process is quite complex and has been sometimes controversial with different studies displaying conflicting results. The MAPK/ERK, JNK and p38MAPK signaling pathways are regulated after nerve injury. MAPK/ERK is involved in many physiological processes including metabolism, survival, apoptosis, proliferation and cell differentiation [88, 89]. In both PNS and CNS, the ERK1/2 pathway appears critical for myelination and myelin maintenance [90-92]. However, SCs respond to peripheral nerve injury by a strong activation of the ERK pathway [93] and in the absence of nerve injury, sustained activation of the ERK pathway in SCs is sufficient to drive demyelination and induce an inflammatory response [86]. The latter findings would be compatible with the idea that c-Jun is a downstream target of ERK signaling [86], although this hypothesis is quite controversial. Indeed, while some authors showed that in vivo ERK overactivation induces c-Jun upregulation and ERK inhibition negatively affects demyelination and c-Jun expression in myelinating co-cultures [86, 94], others reported that c-Jun upregulation and SC demyelination are JNK or p38MAPK-dependent [13, 95, 96]. Moreover, Cervellini et al. [97] reported that sustained activation of the ERK pathway in injured nerves resulted in delayed repair and functional recovery. Indeed, this study shows that early after injury, myelin clearance is faster in mutant mice expressing high and sustained levels of MAPK/ERK in SCs, but 4 weeks following injury, mutant nerves display reduced myelin compaction, reduced number of Cajal bands, decreased internodal length and fewer regenerated axons [97]. Other studies showed instead promyelinating effects of ERK activation and that ERK ablation results in inhibition of SC differentiation and myelination in vivo $[92,98,99]$. These apparent contradictory functions suggest that MAPK/ERK acts over multiple pathways regulating different processes during development and the repair program. More work is, however, required to address this hypothesis.

Another member of the MAPK family, p38MAPK, has also been shown to play a critical role in SC plasticity following injury. It has been suggested that by mediating laminin signaling, p38MAPK regulates SC elongation and alignment along axons, which is required for myelination [100]. In the CNS, p38MAPK has also been shown to be essential during development for oligodendrocyte progenitor proliferation, differentiation and myelination [101-104]. 
However, a different role has been proposed for $\mathrm{p} 38 \mathrm{MAK}$ during the repair program. Following peripheral nerve injury, p38MAPK appears important to initiate the injury response. Early after injury, p38MAPK activity is rapidly increased [85] and in vivo inactivation blocks SC demyelination and conversion into repair cells in the distal nerve [96]. Indeed, p38MAPK promotes SC demyelination and conversion into repair SCs by downregulating myelin proteins and upregulating c-Jun expression [96]. This study also suggests that p38MAPK mediates myelin breakdown and inactivation promotes myelination in co-cultures. Moreover, by employing a $p 38 a$ mutant mouse line, which displays a limited gene loss-of-function, Kato et al. [105] reported that the p38MAPK signaling is also important to initiate the inflammatory response after lesion. Indeed, p38a insufficiency results in inflammatory disorder and delay of histological and functional nerve recovery [105]. Therefore, several evidences support the role of p38 MAPK as a negative regulator of SC myelination, driving the initial response to injury.

Such as the ERK1/2 and the p38MAPK pathways, the JNK pathway is also rapidly activated after nerve injury [81] and has also been involved in several important functions controlling SC plasticity. In in vitro experiments, JNK activation results in the inhibition of myelin gene expression, SC demyelination, proliferation, upregulation and phosphorylation of c-Jun [75, 80, 81, 95, 106-108]. Indeed, c-Jun is known to be a major phosphorylation target of JNK, although the requirement of phospho-c-Jun after nerve injury has not yet been clarified [13, 95]. However, in the distal stump of injured nerves, JNK inhibition decelerates myelin fragmentation [109], which suggests a function of c-Jun phosphorylation in accelerating demyelination. Consistent with this hypothesis, the JNK1/c-Jun pathway can stimulate autophagy in several cell types [110] and pharmacological or genetic inactivation reduces SC autophagic flux [4]. Therefore, the JNK pathway appears to regulate several aspects of the $\mathrm{SC}$ repair program by promoting the activation of c-Jun and expression of others factors associated with the repair program, such as GDNF and P75NTR [13].

\section{Sox 2 and nerve bridge tissue formation}

Regeneration and reinnervation are often successful after nerve crush injuries, as the basal lamina surrounding the axons is often preserved. Regeneration after more severe injuries such as nerve transection is, however, generally less efficient. Indeed, upon cut, a gap forms between the two nerve stumps [111]. A proper regeneration and reinnervation requires the formation of a bridge connecting the two extremities. Sox 2 has been identified as another negative regulator of myelination and remyelination induced in repair cells after injury $[112,113]$, and has been shown to play an important role in tissue bridge formation between the proximal and distal nerve stumps by mediating the ephrin-B/ EphB2 signaling between fibroblasts and SCs and the relocalization of N-cadherin between SCs [26]. Ephrin/Eph is an important mediator of bidirectional signaling between axons and glial cells in the nervous system and has already been shown to be involved in multiple processes such as scar formation, axon guidance, axonal regeneration, and myelination [114]. Nerve damage repair SCs gather at both nerve stumps, where they come into direct contact with fibroblasts, which accumulate at the wound site. Ephrin-B/EphB2 mediate the cell sorting and orchestrate the collective migration of SCs to form multicellular cords that guide and direct the axons across the injury site. Indeed, it has been shown that both pharmacological inhibition and genetical ablation of EphB2 resulted in significantly shorter and less organized regrowing axons as compared to untreated and wild type animals [26]. Moreover, Dun et al. [115], showed that by regulating the Slit3/Robo1 pathway, Sox 2 is also critical for SC migration in the nerve bridge and axon pathfinding after nerve injury. Indeed, this study shows how Sox 2 loss of function leads to ectopic SC migration and to the inability to form proper SC cords connecting the nerves stumps [115]. It has previously been shown that Slit-Robo interaction is crucial for axon guidance and serves as a repulsive signaling to control axon pathfinding and neuronal migration during nervous system development [116]. In their study, Dun et al. showed that Sox 2 regulates Robo1 receptor expression in migrating SCs and that macrophages in the outermost layer of the nerve bridge secrete high levels of its ligand Slit3. Further gene ablation experiments confirm that Slit3/Robo1 repulsive signal is crucial for SC migration trajectory and correct nerve bridge formation following nerve transection [115]. Taken together these results suggest that the coordinated action of different cell types and the combined function of multiple axon guidance molecules is necessary for a correct nerve bridge tissue formation and precise axon targeting in the nerve bridge. Indeed, it has also been shown that a crosstalk between macrophages and endothelial cells is both necessary and sufficient for SCs to find their way across the bridge [117]. In this study, Cattin et al. [117] found that macrophages respond to hypoxia within the bridge by secreting VEGF-A, which triggers the polarized formation of new blood vessels across the bridge region. These new blood vessels are then used by SCs as a path to cross the bridge and guide the regrowing axons. The authors show that these newly formed blood vessels are critical for SC guidance. Indeed, in vivo disruption of their organization either by angiogenic signal inhibition or by forcing their re-orientation compromises SC directionality, resulting in defective nerve repair [117]. 


\section{STAT3 and repair SCs}

STAT3 has been identified as a critical factor promoting a regeneration-supportive environment following nerve injury. Indeed, Benito et al. [118] showed that STAT3 activation by phosphorylation of Tyr705 in SCs is sustained during longterm denervation and is required for both the maintenance of SC autocrine survival signals and the maintenance of the $\mathrm{SC}$ repair phenotype during the regeneration process. In this study, the authors show that STAT3 ablation results in an abnormal morphology of both repair cells and regeneration tracks, failure to sustain the expression of key markers of repair SCs such as c-Jun, Olig1 and Shh, and reduction in the expression of regeneration supportive factors including GDNF and BDNF in the distal stumps [118].

\section{Notch signaling}

The Notch signaling has been identified as a complex regulatory pathway which plays important functions in SCs, both during development and adulthood [119, 120]. Indeed, Notch promotes the generation of SCs from SC precursors and regulates SC proliferation in the developing stage [119]. Notch inhibits myelination and its expression is downregulated at the beginning of the myelination process [121]. Moreover, Notch antagonistic activity to Krox 20 classifies it as a negative regulator of myelination [17]. In adult nerves, Notch dysregulation results in demyelination, which suggests an involvement in the signaling pathway that induces myelin breakdown in vivo. Indeed, inhibition of Notch signaling in adult mice decelerates myelin breakdown that occurs after a nerve lesion [120]. In addition, Wang et al. [122] showed how the addition of Jagged1, a Notch activator, in rat injured nerves enhances functional nerve repair, suggesting that Notch stimulation in SCs could represent an interesting therapeutic strategy promoting nerve repair.

\section{Conclusion}

The PNS displays a remarkable ability to regenerate following injury. This process involves the coordinated action of multiple cell types and signaling pathways. Early after injury, damaged axons respond by generating a distress signal detected by SCs, which initiate the repair program. SCs respond by undergoing dynamic reprogramming and assuming an alternative differentiation state suited to meet the specific requirements arising from the injured condition. Although peripheral nerves display an impressive regenerative capacity as compared to the CNS, recovery for patients suffering from traumatic injuries and others peripheral neuropathies is often incomplete. This is mainly a result of the slow regeneration rate, which can reach approximately $1 \mathrm{~mm}$ per day, depending on the lesion site, and on the absence of a long-lasting repair-supportive environment. Moreover, the PNS repair ability decreases over time. SCs slowly lose their plasticity in an age-dependent way and the PNS environment becomes unsupportive to regeneration [45, 123]. Therefore, a greater understanding of the mechanisms driving SC plasticity is of utmost interest. Extensive research has been devoted to highlight the molecular mechanisms involved in SC reprogramming to provide mechanistic insights and novel therapeutic strategies to treat peripheral nerve injuries as well as to identify possible correlations with CNS mechanisms and strategies to improve CNS regeneration. Recent work demonstrates the involvement of morphogenetic transformations, epigenetic mechanisms and highlight many transcription factors and signaling pathways critical in this process. However, their induction and the temporal/ quantitative activation as well as their mutual interactions have not been completely elucidated and future work should focus on learning how to manipulate repair cells, how to increase their repair-supportive functions, and how to extend their actions to meet the long periods required for axonal regeneration in clinical environment.

Acknowledgements Open Access funding provided by Projekt DEAL. Grant sponsors: International Foundation for Research in Paraplegia (IRP), Grant no. P 174.

Open Access This article is licensed under a Creative Commons Attribution 4.0 International License, which permits use, sharing, adaptation, distribution and reproduction in any medium or format, as long as you give appropriate credit to the original author(s) and the source, provide a link to the Creative Commons licence, and indicate if changes were made. The images or other third party material in this article are included in the article's Creative Commons licence, unless indicated otherwise in a credit line to the material. If material is not included in the article's Creative Commons licence and your intended use is not permitted by statutory regulation or exceeds the permitted use, you will need to obtain permission directly from the copyright holder. To view a copy of this licence, visit http://creativecommons.org/licenses/by/4.0/.

\section{References}

1. Jessen KR, Arthur-Farraj P (2019) Repair Schwann cell update: adaptive reprogramming, EMT, and stemness in regenerating nerves. Glia 67:421-437. https://doi.org/10.1002/glia.23532

2. Jacob C (2017) Chromatin-remodeling enzymes in control of Schwann cell development, maintenance and plasticity. Curr Opin Neurobiol 47:24-30. https://doi.org/10.1016/j. conb.2017.08.007

3. Arthur-Farraj PJ, Latouche M, Wilton DK, Quintes S, Chabrol E, Banerjee A, Woodhoo A, Jenkins B, Rahman M, Turmaine M, Wicher GK, Mitter R, Greensmith L, Behrens A, Raivich G, Mirsky R, Jessen KR (2012) c-Jun reprograms Schwann cells of injured nerves to generate a repair cell essential for regeneration. Neuron 75:633-647. https://doi.org/10.1016/j.neuro n.2012.06.021 
4. Gomez-Sanchez JA, Carty L, Iruarrizaga-Lejarreta M, PalomoIrigoyen M, Varela-Rey M, Mirsky R, Woodhoo A, Jessen KR (2015) Schwann cell autophagy, myelinophagy, initiates myelin clearance from injured nerves. Glia 63:E127-E128. https://doi. org/10.1083/jcb.201503019

5. Jessen KR, Mirsky R (2016) The repair Schwann cell and its function in regenerating nerves. J Physiol Lond 594:3521-3531. https://doi.org/10.1113/Jp270874

6. Madduri S, Gander B (2010) Schwann cell delivery of neurotrophic factors for peripheral nerve regeneration. J Peripher Nerv Syst 15:93-103. https://doi.org/10.1111/j.1529-8027.2010.00257 .x

7. Jessen KR, Mirsky R, Lloyd AC (2015) Schwann cells: development and role in nerve repair. Cold Spring Harb Perspect Biol 7:a020487. https://doi.org/10.1101/cshperspect.a020487

8. Seddon HJ (1943) Peripheral nerve injuries. Glasgow Med J 139:61-75

9. Menorca RMG, Fussell TS, Elfar JC (2013) Nerve physiology mechanisms of injury and recovery. Hand Clin 29:317-330. https ://doi.org/10.1016/j.hcl.2013.04.002

10. Sunderland S (1951) A classification of peripheral nerve injuries producing loss of function. Brain 74:491-516. https://doi. org/10.1093/brain/74.4.491

11. Bauder AR, Ferguson TA (2012) Reproducible mouse sciatic nerve crush and subsequent assessment of regeneration by whole mount muscle analysis. J Vis Exp 60:3606. https://doi. org/10.3791/3606

12. Luis AL, Rodrigues JM, Geuna S, Amado S, Shirosaki Y, Lee JM, Fregnan F, Lopes MA, Veloso AP, Ferreira AJ, Santos JD, Armada-Da-silva PA, Varejao AS, Mauricio AC (2008) Use of PLGA 90:10 scaffolds enriched with in vitro-differentiated neural cells for repairing rat sciatic nerve defects. Tissue Eng Part A 14:979-993. https://doi.org/10.1089/ten.tea.2007.0273

13. Shin YK, Jang SY, Park JY, Park SY, Lee HJ, Suh DJ, Park HT (2013) The Neuregulin-Rac-Mkk7 pathway regulates antagonistic c-Jun/Krox20 expression in Schwann cell dedifferentiation. Glia 6:892-904. https://doi.org/10.1002/glia.22482

14. Schmid D, Zeis T, Schaeren-Wiemers N (2014) Transcriptional regulation induced by cAMP elevation in mouse Schwann cells. ASN Neuro 6:137-157. https://doi.org/10.1042/AN201 30031

15. Vaquie A, Sauvain A, Jacob C (2018) Modeling PNS and CNS myelination using microfluidic chambers. Methods Mol Biol 1791:157-168. https://doi.org/10.1007/978-1-4939-7862-5_12

16. Vaquie A, Sauvain A, Duman M, Nocera G, Egger B, Meyenhofer F, Falquet L, Bartesaghi L, Chrast R, Lamy CM, Bang S, Lee SR, Jeon NL, Ruff S, Jacob C (2019) Injured axons instruct Schwann cells to build constricting actin spheres to accelerate axonal disintegration. Cell Rep 27:3152-3166.e7. https://doi. org/10.1016/j.celrep.2019.05.060

17. Jessen KR, Mirsky R (2008) Negative regulation of myelination: relevance for development, injury, and demyelinating disease. Glia 56:1552-1565. https://doi.org/10.1002/glia.20761

18. Chen ZL, Yu WM, Strickland S (2007) Peripheral regeneration. Annu Rev Neurosci 30:209-233. https://doi.org/10.1146/annur ev.neuro.30.051606.094337

19. Fontana X, Hristova M, Da Costa C, Patodia S, Thei L, Makwana M, Spencer-Dene B, Latouche M, Mirsky R, Jessen KR, Klein R, Raivich G, Behrens A (2012) c-Jun in Schwann cells promotes axonal regeneration and motoneuron survival via paracrine signaling. J Cell Biol 198:127-141. https://doi.org/10.1083/ jcb. 201205025

20. Scheib J, Hoke A (2013) Advances in peripheral nerve regeneration. Nat Rev Neurol 9:668-676. https://doi.org/10.1038/nrneu rol.2013.227
21. Martini R, Fischer S, Lopez-Vales R, David S (2008) Interactions between Schwann cells and macrophages in injury and inherited demyelinating disease. Glia 56:1566-1577. https:// doi.org/10.1002/glia.20766

22. Gitik M, Liraz-Zaltsman S, Oldenborg PA, Reichert F, Rotshenker S (2011) Myelin down-regulates myelin phagocytosis by microglia and macrophages through interactions between CD47 on myelin and SIRP $\alpha$ (signal regulatory protein- $\alpha$ ) on phagocytes. J Neuroinflammation 8:24. https://doi. org/10.1186/1742-2094-8-24

23. Bauer S, Kerr BJ, Patterson PH (2007) The neuropoietic cytokine family in development, plasticity, disease and injury. Nat Rev Neurosci 8:221-232. https://doi.org/10.1038/nrn2054

24. Cafferty WBJ, Gardiner NJ, Gavazzi I, Powell J, McMahon SB, Heath JK, Munson J, Cohen J, Thompson SWN (2001) Leukemia inhibitory factor determines the growth status of injured adult sensory neurons. J Neurosci 21:7161-7170. https://doi. org/10.1523/Jneurosci.21-18-07161.2001

25. Gomez-Sanchez JA, Pilch KS, van der Lans M, Fazal SV, Benito C, Wagstaff LJ, Mirsky R, Jessen KR (2017) After nerve injury, lineage tracing shows that myelin and remak schwann cells elongate extensively and branch to form repair Schwann cells, which shorten radically on remyelination. J Neurosci 37:9086-9099. https://doi.org/10.1523/Jneurosci.1453-17.2017

26. Parrinello S, Napoli I, Ribeiro S, Digby PW, Fedorova M, Parkinson DB, Doddrell RDS, Nakayama M, Adams RH, Lloyd $A C$ (2010) EphB signaling directs peripheral nerve regeneration through Sox2-dependent schwann cell sorting. Cell 143:145155. https://doi.org/10.1016/j.cell.2010.08.039

27. Fricker FR, Bennett DL (2011) The role of neuregulin-1 in the response to nerve injury. Future Neurol 6:809-822. https://doi. org/10.2217/fnl.11.45

28. Quintes S, Brinkmann BG, Ebert M, Frob F, Kungl T, Arlt FA, Tarabykin V, Huylebroeck D, Meijer D, Suter U, Wegner M, Sereda MW, Nave KA (2016) Zeb2 is essential for Schwann cell differentiation, myelination and nerve repair. Nat Neurosci 19:1050-1059. https://doi.org/10.1038/nn.4321

29. Brugger V, Duman M, Bochud M, Munger E, Heller M, Ruff S, Jacob C (2017) Delaying histone deacetylase response to injury accelerates conversion into repair Schwann cells and nerve regeneration. Nat Commun 8:14272. https://doi.org/10.1038/ncomm s14272

30. Ma KH, Svaren J (2016) Epigenomic reprogramming in peripheral nerve injury. Neural Regener Res 11:1930-1931. https://doi. org/10.4103/1673-5374.197133

31. Ma KH, Svaren J (2018) Epigenetic control of Schwann cells. Neuroscientist 24:627-638. https://doi.org/10.1177/1073858417 751112

32. Hung HA, Sun GN, Keles S, Svaren J (2015) Dynamic regulation of Schwann cell enhancers after peripheral nerve injury. J Biol Chem 290:6937-6950. https://doi.org/10.1074/jbc.M114.62287 8

33. Brugger V, Engler S, Pereira JA, Ruff S, Horn M, Welzl H, Munger E, Vaquie A, Sidiropoulos PN, Egger B, Yotovski P, Filgueira L, Somandin C, Luhmann TC, D'Antonio M, Yamaguchi T, Matthias P, Suter U, Jacob C (2015) HDAC1/2-dependent $\mathrm{P} 0$ expression maintains paranodal and nodal integrity independently of myelin stability through interactions with neurofascins. PLoS Biol 13:e1002258. https://doi.org/10.1371/journ al.pbio. 1002258

34. Gordon T, Chan KM, Sulaiman OAR, Udina E, Amirjani N, Brushart TM (2009) Accelerating axon growth to overcome limitations in functional recovery after peripheral nerve injury. Neurosurgery 65:A132-A144. https://doi.org/10.1227/01.Neu.00003 35650.09473.D3 
35. He XL, Zhang LG, Queme LF, Liu XZ, Lu A, Waclaw RR, Dong XR, Zhou WH, Kidd G, Yoon SO, Buonanno A, Rubin JB, Xin M, Nave KA, Trapp BD, Jankowski MP, Lu QR (2018) A histone deacetylase 3-dependent pathway delimits peripheral myelin growth and functional regeneration. Nat Med 24:338-351. https ://doi.org/10.1038/nm.4483

36. Rosenberg LH, Cattin AL, Fontana X, Harford-Wright E, Burden JJ, White IJ, Smith JG, Napoli I, Quereda V, Policarpi C, Freeman J, Ketteler R, Riccio A, Lloyd AC (2018) HDAC3 regulates the transition to the homeostatic myelinating Schwann cell state. Cell Rep 25:2755-2765. https://doi.org/10.1016/j.celre p.2018.11.045

37. Gomez-Sanchez JA, Gomis-Coloma C, Morenilla-Palao C, Peiro G, Serra E, Serrano M, Cabedo H (2013) Epigenetic induction of the Ink4a/Arf locus prevents Schwann cell overproliferation during nerve regeneration and after tumorigenic challenge. Brain 136:2262-2278. https://doi.org/10.1093/brain/awt130

38. Wong KM, Babetto E, Beirowski B (2017) Axon degeneration: make the Schwann cell great again. Neural Regen Res 12:518524. https://doi.org/10.4103/1673-5374.205000

39. Vargas ME, Barres BA (2007) Why is Wallerian degeneration in the CNS so slow? Annu Rev Neurosci 30:153-179. https://doi. org/10.1146/annurev.neuro.30.051606.094354

40. Beirowski B, Adalbert R, Wagner D, Grumme DS, Addicks K, Ribchester RR, Coleman MP (2005) The progressive nature of Wallerian degeneration in wild-type and slow Wallerian degeneration (Wld(S)) nerves. BMC Neurosci 6:6. https://doi. org/10.1186/1471-2202-6-6

41. Brown MC, Lunn ER, Perry VH (1992) Consequences of slow Wallerian degeneration for regenerating motor and sensory axons. J Neurobiol 23:521-536. https://doi.org/10.1002/ neu. 480230507

42. Chen S, Bisby MA (1993) Impaired motor axon regeneration in the C57bl/Ola mouse. J Comp Neurol 333:449-454. https://doi. org/10.1002/cne. 903330310

43. Huebner EA, Strittmatter SM (2009) Axon regeneration in the peripheral and central nervous systems. Results Probl Cell Differ 48:339-351. https://doi.org/10.1007/400_2009_19

44. Lutz AB, Chung WS, Sloan SA, Carson GA, Zhou L, Lovelett E, Posada S, Zuchero JB, Barres BA (2017) Schwann cells use TAM receptor-mediated phagocytosis in addition to autophagy to clear myelin in a mouse model of nerve injury. Proc Natl Acad Sci USA 114:E8072-E8080. https://doi.org/10.1073/pnas.17105 66114

45. Painter MW, Lutz AB, Cheng YC, Latremoliere A, Duong K, Miller CM, Posada S, Cobos EJ, Zhang AX, Wagers AJ, Havton LA, Barres B, Omura T, Woolf CJ (2014) Diminished Schwann cell repair responses underlie age-associated impaired axonal regeneration. Neuron 83:331-343. https://doi.org/10.1016/j. neuron.2014.06.016

46. Jha AK, Huang SCC, Sergushichev A, Lampropoulou V, Ivanova Y, Loginicheva E, Chmielewski K, Stewart KM, Ashall J, Everts B, Pearce EJ, Driggers EM, Artyomov MN (2015) Network integration of parallel metabolic and transcriptional data reveals metabolic modules that regulate macrophage polarization. Immunity 42:419-430. https://doi.org/10.1016/j.immuni.2015.02.005

47. Tofaris GK, Patterson PH, Jessen KR, Mirsky R (2002) Denervated Schwann cells attract macrophages by secretion of leukemia inhibitory factor (LIF) and monocyte chemoattractant protein- 1 in a process regulated by interleukin- 6 and LIF. J Neurosci 22:6696-6703

48. Klein D, Martini R (2016) Myelin and macrophages in the PNS: An intimate relationship in trauma and disease. Brain Res 1641:130-138. https://doi.org/10.1016/j.brainres.2015.11.033
49. Brinkmann BG, Agarwal A, Sereda MW, Garratt AN, Mueller T, Wende H, Stassart RM, Nawaz S, Humml C, Velanac V, Radyushkin K, Goebbels S, Fischer TM, Franklin RJ, Lai C, Ehrenreich H, Birchmeier C, Schwab MH, Nave KA (2008) Neuregulin-1/ErbB signaling serves distinct functions in myelination of the peripheral and central nervous system. Neuron 59:581-595. https://doi.org/10.1016/j.neuron.2008.06.028

50. Chen S, Velardez MO, Warot X, Yu ZX, Miller SJ, Cros D, Corfas $G$ (2006) Neuregulin 1-erbB signaling is necessary for normal myelination and sensory function. J Neurosci 26:3079-3086. https://doi.org/10.1523/Jneurosci.3785-05.2006

51. Freidin M, Asche S, Bargiello TA, Bennett MVL, Abrams CK (2009) Connexin 32 increases the proliferative response of Schwann cells to neuregulin-1 (Nrg1). Proc Natl Acad Sci USA 106:3567-3572. https://doi.org/10.1073/pnas.0813413106

52. Leimeroth R, Lobsiger C, Lussi A, Taylor V, Suter U, Sommer L (2002) Membrane-bound neuregulin1 type III actively promotes Schwann cell differentiation of multipotent progenitor cells. Dev Biol 246:245-258. https://doi.org/10.1006/dbio.2002.0670

53. Michailov GV, Sereda MW, Brinkmann BG, Fischer TM, Haug B, Birchmeier C, Role L, Lai C, Schwab MH, Nave KA (2004) Axonal neuregulin-1 regulates myelin sheath thickness. Science 304:700-703. https://doi.org/10.1126/science.1095862

54. Morris JK, Lin WC, Hauser C, Marchuk Y, Getman D, Lee KF (1999) Rescue of the cardiac defect in ErbB2 mutant mice reveals essential roles of ErbB2 in peripheral nervous system development. Neuron 23:273-283. https://doi.org/10.1016/S0896 $-6273(00) 80779-5$

55. Newbern J, Birchmeier C (2010) Nrg1/ErbB signaling networks in Schwann cell development and myelination. Semin Cell Dev Biol 21:922-928. https://doi.org/10.1016/j.semcdb.2010.08.008

56. Syroid DE, Maycox PR, Burrola PG, Liu NL, Wen DZ, Lee KF, Lemke G, Kilpatrick TJ (1996) Cell death in the Schwann cell lineage and its regulation by neuregulin. Proc Natl Acad Sci USA 93:9229-9234. https://doi.org/10.1073/pnas.93.17.9229

57. Taveggia C, Zanazzi G, Petrylak A, Yano H, Rosenbluth J, Einheber S, Xu XR, Esper RM, Loeb JA, Shrager P, Chao MV, Falls DL, Role L, Salzer JL (2005) Neuregulin-1 type III determines the ensheathment fate of axons. Neuron 47:681-694. https://doi. org/10.1016/j.neuron.2005.08.017

58. Atanasoski S, Scherer SS, Sirkowski E, Leone D, Garratt AN, Birchmeier C, Suter U (2006) ErbB2 signaling in Schwann cells is mostly dispensable for maintenance of myelinated peripheral nerves and proliferation of adult Schwann cells after injury. J Neurosci 26:2124-2131. https://doi.org/10.1523/Jneur osci.4594-05.2006

59. Carroll SL, Miller ML, Frohnert PW, Kim SS, Corbett JA (1997) Expression of neuregulins and their putative receptors, ErbB2 and ErbB3, is induced during Wallerian degeneration. J Neurosci $17: 1642-1659$

60. Kwon YK, Bhattacharyya A, Alberta JA, Giannobile WV, Cheon KW, Stiles CD, Pomeroy SL (1997) Activation of ErbB2 during Wallerian degeneration of sciatic nerve. J Neurosci 17:8293-8299

61. Ronchi G, Haastert-Talini K, Fornasari BE, Perroteau I, Geuna S, Gambarotta G (2016) The Neuregulin1/ErbB system is selectively regulated during peripheral nerve degeneration and regeneration. Eur J Neurosci 43:351-364. https://doi.org/10.1111/ ejn. 12974

62. Bermingham-McDonogh O, Xu YT, Marchionni MA, Scherer SS (1997) Neuregulin expression in PNS neurons: isoforms and regulation by target interactions. Mol Cell Neurosci 10:184-195. https://doi.org/10.1006/mcne.1997.0654

63. Chen SZ, Rio C, Ji RR, Dikkes P, Coggeshall RE, Woolf CJ, Corfas G (2003) Disruption of ErbB receptor signaling in adult 
non-myelinating Schwann cells causes progressive sensory loss. Nat Neurosci 6:1186-1193. https://doi.org/10.1038/nn1139

64. Fricker FR, Antunes-Martins A, Galino J, Paramsothy R, La Russa F, Perkins J, Goldberg R, Brelstaff J, Zhu N, McMahon SB, Orengo C, Garratt AN, Birchmeier C, Bennett DLH (2013) Axonal neuregulin 1 is a rate limiting but not essential factor for nerve remyelination. Brain 136:2279-2297. https://doi. org/10.1093/brain/awt148

65. Hu XY, Hicks CW, He WX, Wong P, Macklin WB, Trapp BD, Yan RQ (2006) Bace1 modulates myelination in the central and peripheral nervous system. Nat Neurosci 9:1520-1525. https:// doi.org/10.1038/nn1797

66. Willem M, Garratt AN, Novak B, Citron M, Kaufmann S, Rittger A, DeStrooper B, Saftig P, Birchmeier C, Haass C (2006) Control of peripheral nerve myelination by the beta-secretase BACE1. Science 314:664-666. https://doi.org/10.1126/science.1132341

67. Farah MH, Pan BH, Hoffman PN, Ferraris D, Tsukamoto T, Nguyen T, Wong PC, Price DL, Slusher BS, Griffin JW (2011) Reduced BACE1 activity enhances clearance of myelin debris and regeneration of axons in the injured peripheral nervous system. J Neurosci 31:5744-5754. https://doi.org/10.1523/Jneur osci.6810-10.2011

68. Hu XY, He WX, Diaconu CD, Tang XY, Kidd GJ, Macklin WB, Trapp BD, Yan RQ (2008) Genetic deletion of BACE1 in mice affects remyelination of sciatic nerves. FASEB J 22:2970-2980. https://doi.org/10.1096/fj.08-106666

69. Stassart RM, Fledrich R, Velanac V, Brinkmann BG, Schwab MH, Meijer D, Sereda MW, Nave KA (2013) A role for Schwann cell-derived neuregulin-1 in remyelination. Nat Neurosci 16:4854. https://doi.org/10.1038/nn.3281

70. Chen LE, Liu K, Seaber AV, Katragadda S, Kirk C, Urbaniak JR (1998) Recombinant human glial growth factor 2 (rhGGF2) improves functional recovery of crushed peripheral nerve (a double-blind study). Neurochem Int 33:341-351. https://doi. org/10.1016/s0197-0186(98)00037-0

71. Joung I, Yoo M, Woo JH, Chang CY, Heo H, Kwon YK (2010) Secretion of EGF-like domain of heregulin beta promotes axonal growth and functional recovery of injured sciatic nerve. Mol Cells 30:477-484. https://doi.org/10.1007/s10059-010-0137-5

72. Yildiz M, Karlidag T, Yalcin S, Ozogul C, Keles E, Alpay HC, Yanilmaz M (2011) Efficacy of glial growth factor and nerve growth factor on the recovery of traumatic facial paralysis. Eur Arch Otorhinolaryngol 268:1127-1133. https://doi.org/10.1007/ s00405-011-1492-3

73. Guertin AD, Zhang DP, Mak KS, Alberta JA, Kim HA (2005) Microanatomy of axon/glial signaling during Wallerian degeneration. J Neurosci 25:3478-3487. https://doi.org/10.1523/Jneur osci.3766-04.2005

74. Fledrich R, Akkermann D, Schütza V, Abdelaal TA, Hermes D, Schäffner E, Soto-Bernardini MC, Götze T, Klink A, Kusch K, Krueger M, Kungl T, Frydrychowicz C, Möbius W, Brück W, Mueller WC, Bechmann I, Sereda MW, Schwab MH, Nave KA, Stassart RM (2019) NRG1 type I dependent autoparacrine stimulation of Schwann cells in onion bulbs of peripheral neuropathies. Nat Commun 10:146. https://doi.org/10.1038/s4146 7-019-09385-6

75. Yamauchi J, Miyamoto Y, Chan JR, Tanoue A (2008) ErbB2 directly activates the exchange factor Dock7 to promote Schwann cell migration. J Cell Biol 181:351-365. https://doi.org/10.1083/ jcb. 200709033

76. Hansen JR, Roehm PC, Chatterjee P, Green SH (2006) Constitutive neuregulin-1/ErbB signaling contributes to human vestibular schwannoma proliferation. Glia 53:593-600. https://doi. org/10.1002/glia.20316

77. Tapinos N, Ohnishi M, Rambukkana A (2006) ErbB2 receptor tyrosine kinase signaling mediates early demyelination induced by leprosy bacilli. Nat Med 12:961-966. https://doi.org/10.1038/ nm0906-1100a

78. Zanazzi G, Einheber S, Westreich R, Hannocks MJ, BedellHogan D, Marchionni MA, Salzer JL (2001) Glial growth factor/ neuregulin inhibits Schwann cell myelination and induces demyelination. J Cell Biol 152:1289-1299. https://doi.org/10.1083/ jcb.152.6.1289

79. Defelipe C, Hunt SP (1994) The differential control of c-Jun expression in regenerating sensory neurons and their associated glial-cells. J Neurosci 14:2911-2923

80. Parkinson DB, Bhaskaran A, Droggiti A, Dickinson S, D'Antonio M, Mirsky R, Jessen KR (2004) Krox-20 inhibits Jun-NH2terminal kinase/c-Jun to control Schwann cell proliferation and death. J Cell Biol 164:385-394. https://doi.org/10.1083/ jcb.200307132

81. Parkinson DB, Bhaskaran A, Arthur-Farraj P, Noon LA, Woodhoo A, Lloyd AC, Feltri ML, Wrabetz L, Behrens A, Mirsky R, Jessen KR (2008) c-Jun is a negative regulator of myelination. J Cell Biol 181:625-637. https://doi.org/10.1083/jcb.200803013

82. Klein D, Groh J, Wettmarshausen J, Martini R (2014) Nonuniform molecular features of myelinating Schwann cells in models for CMT1: distinct disease patterns are associated with NCAM and c-Jun upregulation. Glia 62:736-750. https://doi. org/10.1002/glia.22638

83. Hantke J, Carty L, Wagstaff LJ, Turmaine M, Wilton DK, Quintes S, Koltzenburg M, Baas F, Mirsky R, Jessen KR (2014) c-Jun activation in Schwann cells protects against loss of sensory axons in inherited neuropathy. Brain 137:2922-2937. https://doi. org/10.1093/brain/awu257

84. Stratton JA, Shah PT (2016) Macrophage polarization in nerve injury: do Schwann cells play a role? Neural Regen Res 11:5357. https://doi.org/10.4103/1673-5374.175042

85. Myers RR, Sekiguchi Y, Kikuchi S, Scott B, Medicherla S, Protter A, Campana WM (2003) Inhibition of p38 MAP kinase activity enhances axonal regeneration. Exp Neurol 184:606-614. https ://doi.org/10.1016/S0014-4886(03)00297-8

86. Napoli I, Noon LA, Ribeiro S, Kerai AP, Parrinello S, Rosenberg LH, Collins MJ, Harrisingh MC, White IJ, Woodhoo A, Lloyd AC (2012) A central role for the erk-signaling pathway in controlling schwann cell plasticity and peripheral nerve regeneration in vivo. Neuron 73:729-742. https://doi.org/10.1016/j.neuro n.2011.11.031

87. Sheu JY, Kulhanek DJ, Eckenstein FP (2000) Differential patterns of ERK and STAT3 phosphorylation after sciatic nerve transection in the rat. Exp Neurol 166:392-402. https://doi. org/10.1006/exnr.2000.7508

88. Cargnello M, Roux PP (2011) Activation and function of the MAPKs and their substrates, the MAPK-activated protein kinases. Microbiol Mol Biol Rev 75:50-83. https://doi. org/10.1128/Mmbr.00031-10

89. Pearson G, Robinson F, Gibson TB, Xu BE, Karandikar M, Berman K, Cobb MH (2001) Mitogen-activated protein (MAP) kinase pathways: Regulation and physiological functions. Endocr Rev 22:153-183. https://doi.org/10.1210/er.22.2.153

90. Ishii A, Furusho M, Dupree JL, Bansal R (2014) Role of ERK1/2 MAPK signaling in the maintenance of myelin and axonal integrity in the adult CNS. J Neurosci 34:16031-16045. https://doi. org/10.1523/Jneurosci.3360-14.2014

91. Ishii A, Fyffe-Maricich SL, Furusho M, Miller RH, Bansal R (2012) ERK1/ERK2 MAPK signaling is required to increase myelin thickness independent of oligodendrocyte differentiation and initiation of myelination. J Neurosci 32:8855-8864. https:// doi.org/10.1523/Jneurosci.0137-12.2012

92. Newbern JM, Li XY, Shoemaker SE, Zhou JA, Zhong JA, Wu YH, Bonder D, Hollenback S, Coppola G, Geschwind DH, Landreth GE, Sniderl WD (2011) Specific functions for ERK/MAPK 
signaling during PNS development. Neuron 69:91-105. https:// doi.org/10.1016/j.neuron.2010.12.003

93. Harrisingh MC, Perez-Nadales E, Parkinson DB, Malcolm DS, Mudge AW, Lloyd AC (2004) The Ras/Raf/ERK signalling pathway drives Schwann cell dedifferentiation. EMBO J 23:30613071. https://doi.org/10.1038/sj.emboj.7600309

94. Syed N, Reddy K, Yang DP, Taveggia C, Salzer JL, Maurel P, Kim HA (2010) Soluble Neuregulin-1 Has Bifunctional, Concentration-dependent effects on Schwann cell myelination. J Neurosci 30:6122-6131. https://doi.org/10.1523/Jneur osci.1681-09.2010

95. Monje PV, Soto J, Bacallao K, Wood PM (2010) Schwann cell dedifferentiation is independent of mitogenic signaling and uncoupled to proliferation: role of cAMP and JNK in the maintenance of the differentiated state. J Biol Chem 285:31024-31036. https://doi.org/10.1074/jbc.M110.116970

96. Yang DP, Kim J, Syed N, Tung YJ, Bhaskaran A, Mindos T, Mirsky R, Jessen KR, Maurel P, Parkinson DB, Kim HA (2012) p38 MAPK activation promotes denervated Schwann cell phenotype and functions as a negative regulator of Schwann cell differentiation and myelination. J Neurosci 32:7158-7168. https ://doi.org/10.1523/Jneurosci.5812-11.2012

97. Cervellini I, Galino J, Zhu N, Allen S, Birchmeier C, Bennett DL (2018) Sustained MAPK/ERK activation in adult Schwann cells impairs nerve repair. J Neurosci 38:679-690. https://doi. org/10.1523/Jneurosci.2255-17.2017

98. Grossmann KS, Wende H, Paul FE, Cheret C, Garratt AN, Zurborg S, Feinberg K, Besser D, Schulz H, Peles E, Selbach M, Birchmeier W, Birchmeier C (2009) The tyrosine phosphatase Shp2 (PTPN11) directs Neuregulin-1/ErbB signaling throughout Schwann cell development. Proc Natl Acad Sci USA 106:1670416709. https://doi.org/10.1073/pnas.0904336106

99. He Y, Kim JY, Dupree J, Tewari A, Melendez-Vasquez C, Svaren J, Casaccia P (2010) Yy1 as a molecular link between neuregulin and transcriptional modulation of peripheral myelination. Nat Neurosci 13:1472-1480. https://doi.org/10.1038/nn.2686

100. Haines JD, Fragoso G, Hossain S, Mushynski WE, Almazan G (2008) p38 Mitogen-activated protein kinase regulates myelination. J Mol Neurosci 35:23-33. https://doi.org/10.1007/s1203 1-007-9011-0

101. Baron W, Metz B, Bansal R, Hoekstra D, de Vries H (2000) PDGF and FGF-2 signaling in oligodendrocyte progenitor cells: regulation of proliferation and differentiation by multiple intracellular signaling pathways. Mol Cell Neurosci 15:314-329. https://doi.org/10.1006/mcne.1999.0827

102. Bhat NR, Zhang PS, Mohanty SB (2007) p38 MAP kinase regulation of oligodendrocyte differentiation with CREB as a potential target. Neurochem Res 32:293-302. https://doi.org/10.1007/ s11064-006-9274-9

103. Chew LJ, Coley W, Cheng Y, Gallo V (2010) Mechanisms of regulation of oligodendrocyte development by p38 mitogenactivated protein kinase. J Neurosci 30:11011-11027. https:// doi.org/10.1523/Jneurosci.2546-10.2010

104. Fragoso G, Haines JD, Roberston J, Pedraza L, Mushynski WE, Almazan G (2007) p38 Mitogen-activated protein kinase is required for central nervous system myelination. Glia 55:15311541. https://doi.org/10.1002/glia.20567

105. Kato N, Matsumoto M, Kogawa M, Atkins GJ, Findlay DM, Fujikawa T, Oda H, Ogata M (2013) Critical role of p38 MAPK for regeneration of the sciatic nerve following crush injury in vivo. J Neuroinflam 10(1):1. https://doi.org/10.1186/1742-2094-10-1

106. Apra C, Richard L, Coulpier F, Blugeon C, Gilardi-Hebenstreit P, Vallat JM, Lindner V, Charnay P, Decker L (2012) Cthrc1 is a negative regulator of myelination in schwann cells. Glia 60:393-403. https://doi.org/10.1002/glia.22273
107. Yamauchi J, Chan JR, Shooter EM (2003) Neurotrophin 3 activation of TrkC induces Schwann cell migration through the c-Jun N-terminal kinase pathway. Proc Natl Acad Sci USA 100:1442114426. https://doi.org/10.1073/pnas.2336152100

108. Yamauchi J, Miyamoto Y, Hamasaki H, Sanbe A, Kusakawa S, Nakamura A, Tsumura H, Maeda M, Nemoto N, Kawahara K, Torii T, Tanoue A (2011) The atypical guanine-nucleotide exchange factor, Dock7, negatively regulates Schwann cell differentiation and myelination. J Neurosci 31:12579-12592. https ://doi.org/10.1523/Jneurosci.2738-11.2011

109. Jung JU, Cai W, Lee HK, Pellegatta M, Shin YK, Jang SY, Suh DJ, Wrabetz L, Feltri ML, Park HT (2011) Actin polymerization is essential for myelin sheath fragmentation during Wallerian degeneration. J Neurosci 31:2009-2015. https://doi.org/10.1523/ JNEUROSCI.4537-10.2011

110. Pattingre S, Bauvy C, Carpentier S, Levade T, Levine B, Codogno P (2009) Role of JNK1-dependent Bcl-2 phosphorylation in ceramide-induced macroautophagy. J Biol Chem 284:2719-2728. https://doi.org/10.1074/jbc.M805920200

111. Nguyen QT, Sanes JR, Lichtman JW (2002) Pre-existing pathways promote precise projection patterns. Nat Neurosci 5:861867. https://doi.org/10.1038/nn905

112. Roberts SL, Dun XP, Doddrell RDS, Mindos T, Drake LK, Onaitis MW, Florio F, Quattrini A, Lloyd AC, D'Antonio M, Parkinson DB (2017) Sox2 expression in Schwann cells inhibits myelination in vivo and induces influx of macrophages to the nerve. Development 144:3114-3125. https://doi.org/10.1242/ dev. 150656

113. Salzer JL (2008) Switching myelination on and off. J Cell Biol 181:575-577. https://doi.org/10.1083/jcb.200804136

114. Linneberg C, Harboe M, Laursen L (2015) Axo-glia interaction preceding CNS myelination is regulated by bidirectional Ephephrin signaling. ASN Neuro 7:1759091415602859. https://doi. org/10.1177/1759091415602859

115. Dun XP, Carr L, Woodley PK, Barry RW, Drake LK, Mindos T, Roberts SL, Lloyd AC, Parkinson DB (2019) Macrophagederived Slit 3 controls cell migration and axon pathfinding in the peripheral nerve bridge. Cell Rep 26:1458-1472. https://doi. org/10.1016/j.celrep.2018.12.081

116. Blockus H, Chedotal A (2016) Slit-Robo signaling. Development 143:3037-3044. https://doi.org/10.1242/dev.132829

117. Cattin AL, Burden JJ, Van Emmenis L, Mackenzie FE, Hoving JJ, Garcia Calavia N, Guo Y, McLaughlin M, Rosenberg LH, Quereda V, Jamecna D, Napoli I, Parrinello S, Enver T, Ruhrberg C, Lloyd AC (2015) Macrophage-induced blood vessels guide Schwann cell-mediated regeneration of peripheral nerves. Cell 162:1127-1139. https://doi.org/10.1016/j.cell.2015.07.021

118. Benito C, Davis CM, Gomez-Sanchez JA, Turmaine M, Meijer D, Poli V, Mirsky R, Jessen KR (2017) STAT3 controls the long-term survival and phenotype of repair Schwann cells during nerve regeneration. J Neurosci 37:4255-4269. https://doi. org/10.1523/JNEUROSCI.3481-16.2017

119. Zujovic V, Bachelin C, Baron-Van Evercooren A (2007) Remyelination of the central nervous system: a valuable contribution from the periphery. Neuroscientist 13:383-391. https://doi. org/10.1177/10738584070130041001

120. Woodhoo A, Alonso MB, Droggiti A, Turmaine M, D'Antonio M, Parkinson DB, Wilton DK, Al-Shawi R, Simons P, Shen J, Guillemot F, Radtke F, Meijer D, Feltri ML, Wrabetz L, Mirsky R, Jessen KR (2009) Notch controls embryonic Schwann cell differentiation, postnatal myelination and adult plasticity. Nat Neurosci 12:839-847. https://doi.org/10.1038/nn.2323

121. Mirsky R, Woodhoo A, Parkinson DB, Arthur-Farraj P, Bhaskaran A, Jessen KR (2008) Novel signals controlling embryonic Schwann cell development, myelination and 
dedifferentiation. J Peripher Nerv Syst 13:122-135. https://doi. org/10.1111/j.1529-8027.2008.00168.x

122. Wang J, Ren KY, Wang YH, Kou YH, Zhang PX, Peng JP, Deng L, Zhang HB, Jiang BG (2015) Effect of active Notch signaling system on the early repair of rat sciatic nerve injury. Artif Cells Nanomed Biotechnol 43:383-389. https://doi.org/10.3109/21691 401.2014.896372

123. Zochodne DW (2012) The challenges and beauty of peripheral nerve regrowth. J Peripher Nerv Syst 17:1-18. https://doi.org/1 0.1111/j.1529-8027.2012.00378.x
Publisher's Note Springer Nature remains neutral with regard to jurisdictional claims in published maps and institutional affiliations. 